\title{
Editor's Message Isotope techniques for monitoring groundwater salinization
}

\author{
Cheikh B. Gaye, Associate Editor
}

Steady increase in the salinity of most of the major aquifers being used for water supply in the arid and semi-arid regions of Africa and Asia provides evidence of waterquality deterioration. This salinization is often due to inflow of dense saline water during heavy withdrawals of fresh water from coastal aquifers and/or mobilisation of saline groundwaters by the over-exploitation of inland aquifer systems. Water pollution (salinization) due to extensive irrigation and $\mathrm{u} / \mathrm{se}$ of fertilisers and other pesticides is also growing. Since there are several sources for the groundwater-quality deterioration, it is necessary to characterise the specific processes involved. Isotope techniques are particularly effective for identifying the sources of salinity and the inflow of fresh groundwater.

The fundamental relationships between $\delta^{18} \mathrm{O}$ and $\delta^{2} \mathrm{H}$ and between $\delta^{18} \mathrm{O}$ and salinity have been used in previous studies to identify different salinization pathways. These include flushing of airborne salts by precipitation or by dissolution of evaporitic minerals from the surface, the soil, or aquifer materials; and the encroachment of seawater, or the induced flow from pockets of connate brine. Although this basic approach is still valid, in the past decade new isotope tools for investigating the dissolved component (such as $\delta^{37} \mathrm{Cl}$ and $\delta^{11} \mathrm{~B}$ ) have appeared mainly as the results of methodological investigations or in isolated case studies.

The International Atomic Energy Agency (IAEA) has a long tradition and wide experience in the use of isotope techniques for water-resources studies and is acting as the international focal point in promoting the practical application of isotope methods on a wider scale. Over the past decades, the Isotope Hydrology Section of the IAEA has monitored more than 40 research contracts and technical cooperative studies in this field, including determination of the origins of groundwater salinization,

Published online: 11 May 2001

(C) Springer-Verlag 2001

C.B. Gaye (E)

Isotope Hydrology Section,

Department of Nuclear Sciences and Applications,

International Atomic Energy Agency,

Wagramerstrasse 5, P.O. Box 100,

1400 Vienna, Austria assessment of groundwater resources in coastal areas and islands, and evaluation of the effect of irrigation activities on groundwater quality (IAEA 1985, 1996, 1998, 2001). In these studies, both naturally occurring stable and radioactive isotopes were used.

In 2000, the Agency launched a new initiative aimed at investigating the origins of salinity (salinization processes) and their impacts on coastal fresh-water resources using a multi-isotope approach combining various stable and radioactive isotopes (deuterium, tritium, oxygen18, carbon-14, carbon-13, sulphur-34, boron-11, strontium-87, chlorine-36, and iodine-129. The studies will be conducted within the framework of a Coordinated Research Programme (CRP) entitled, "Origins of salinity and impacts on fresh groundwater resources. Optimisation of isotope techniques." Several proposals from contract holders in China, Israel, Jordan, Tunisia, Morocco, Korea, and Pakistan were evaluated in terms of how they meet several pre-defined criteria which were found to be the most important for the selection of a "flagship" site where an international team will conduct a study using a multiple-isotope approach.

The site, in the Souss-Massa coastal plain in southwest Morocco, has been selected because it offered the opportunity to study both coastal saline intrusion and inland-basin problems. The first chemical and isotopic analyses (Ekwurzel et al. 2001; Hsissou et al. 2001) give indications of several possible sources for the groundwater salinity: (1) present-day marine intrusion, (2) old marine intrusion, (3) water-rock interaction and dissolution of evaporites, (4) concentration by evaporation, and (5) anthropogenic pollution.

The economy of the region depends mainly on agriculture, tourism, and maritime fishing. Increases in population and economic development generate growth in demand for water and a proliferation of pollution sources, and this requires good management of the environment in order to preserve water of good quality and sufficient quantity. It is anticipated that the study will result in the precise delineation of the required optimum salinity distribution for improving water-resource management. Although the selection of the flagship site was the main target of the CRP, it was decided also that the opportunities for collaboration between all participants was required and a networking approach would be adopted to achieve these goals. 
Keywords groundwater $\cdot$ salinization $\cdot$ multi-isotope approach

\section{References}

Ekwurzel B, Moran JE, Hudson GB, Bissani M, Blake R, Krimissa M, Mosleh N, Marah H, Sasaf N, Hsissou Y, Bouchaou L (2001) An isotopic investigation of salinity and water sources in the Souss-Massa basin, Morocco. Cyber Proc Salt Water intrusion and Coastal Aquifers First Int Conf

Hsissou Y, Bouchaou L, Krimissa M, Mudry J (2001) Caractérisation de l'origine de la salinité des eaux de la nappe cotière
d'Agadir (Maroc)., Cyber Proc Salt Water intrusion and Coastal Aquifers First Int Conf

International Atomic Energy Agency (1985) Stable and radioactive isotopes in the study of the Unsaturated Soil Zone. TECDOC 357

International Atomic Energy Agency (1996) Isotope field applications for groundwater studies in the Middle East. TECDOC 890

International Atomic Energy Agency (1998) Application of isotope techniques to investigate groundwater pollution. TECDOC 1046

International Atomic Energy Agency (2001) Isotope techniques in water resources investigations in arid and semi-arid regions. TECDOC 1207 